\title{
Oxidized Glutathione Promotes the Association of Proteins from Bean Seeds to Potato Starch
}

\author{
Paola Correa, ${ }^{1}$ Lilia Bernal, ${ }^{2}$ Patricia Coello, ${ }^{1}$ and Eleazar Martínez-Barajas ${ }^{1 *}$ \\ ${ }^{1}$ Departamento de Bioquímica, Facultad de Química, Universidad Nacional Autónoma de México. Ciudad Universitaria, \\ Coyoacán, México 04510, D.F. emtz@servidor.unam.mx \\ 2 Facultad de Ciencias Químicas, Universidad La Salle
}

Dedicated to Dr. Estela Sánchez de Jiménez for her invaluable contributions to plant biochemistry

Received January 6, 2011; accepted May 12, 2011

\begin{abstract}
In this paper, we report the use of oxidized glutathione (GSSG) in promoting the association of bean seed proteins to starch granules purified from potato tubers. The resulting interaction was stable and only a small fraction of the bound proteins was released by washing with $5 \%$ glucose. Higher concentrations of glucose or other sugars (fructose, mannose and mannitol) failed to further increase protein release. Dithiothreitol (DTT) at concentrations up to $50 \mathrm{mM}$ did not liberate the proteins associated to starch; however, applied after GSSG but before adding the proteins, it was very effective in preventing binding of proteins to starch. Lastly, starch modified by the bound proteins increased its water absorption capacity.

Key words: GSSG, starch, starch-protein interaction.
\end{abstract}

\section{Introduction}

Starch is a complex carbohydrate composed of glucose linked through $\alpha-1,4$ and $\alpha-1,6$ glycosidic bonds widely used in food industry. It forms a compact structure (granules) where amylose (almost-linear) and amylopectin (heavily-branched) can be identified as major components [1]. Many features of the starch products depend on the granule size, the ratio amylose: amylopectin as well as the lipids and proteins present on the granule surface [2]. The need for starch with new properties has prompted the search for new ways to change starch features. Some of these successful approaches include physical, chemical or enzymatic modification and the manipulation of different aspects of the biosynthetic pathway by plant breeding, mutant selection and the genetic engineering of plants [1]. Starch granule-associated proteins represent only a minor component but appear to be significantly influential on the overall properties of both starch granules and starchy products [3]. The interaction with different protein sources has been successfully used to change starch properties such as gelatinization temperature, water absorption, syneresis and viscosity, among others $[4,5$, 6]. Hydrophobic interactions have been implicated in the starchprotein association, but several factors may also be involved in this interaction including protein shape, size and charge [7]. The amylopectin content is also important, its ramifications can increase potential interaction with hydrophilic portions of protein molecule [5]. Since it has been reported that the binding of some proteins to starch granules is redox-regulated [8], in this paper we report that oxidized glutathione (GSSG), which is important for cellular redox balance [9], was also very effective
Resumen. En este artículo se reporta el uso del glutatión oxidado (GSSG) como promotor de la asociación de proteínas de semillas de frijol a almidón purificado de tubérculos de papa. La interacción resultante fue estable y solo una pequeña fracción de las proteínas unidas se liberó lavando con glucosa al 5\%. Concentraciones mayores de glucosa o de otros azúcares (fructosa, manosa y manitol) no incrementaron la cantidad de proteína liberada. El ditiotreitol (DTT) en concentraciones de hasta $50 \mathrm{mM}$ tampoco liberó a las proteínas unidas. Sin embargo, aplicado después del GSSG pero antes de agregar a las proteínas es muy efectivo para evitar su unión al almidón. Finalmente, el almidón modificado por la unión de proteínas incrementó significativamente su capacidad de retención de agua.

Palabras clave: GSSG, almidón, interacción proteínas-almidón.

to promote a stable interaction of potato starch with proteins from bean seeds; as a result, the modified starch showed an increased water absorption capacity.

\section{Results and Discussion}

The association of proteins to starch granule surface can have a positive impact in starch products by improving gelatinization temperature, water absorption, syneresis and viscosity among others characteristics of starch $[4,5,6]$, On the other hand, since potato starch granules are usually purified with just few proteins attached to them (data not shown), these granules are a suitable system to work with in order to investigate how the redox environment is involved in the association between starch and proteins from a cheap and easily available source, such as bean seed and how this interaction affects starch properties. Glutathione is formed by the union of cysteine, glycine and glutamate, its reduced (GSH) and oxidized (GSSG) forms act as a homeostatic redox buffer that contributes to the maintenance of the cellular redox balance [9] and is essential for both the normal development of the embryo and for the maturation of the seed [10] and, it has been suggested that this system also works to address the need of developing seeds for sulfur [11]. Since it has been reported that some proteins display a reversible and selective binding to the starch granules depending on redox state [8], therefore, we studied the effect of DTT and GSSG in the interaction between bean seed proteins and starch granules. Figure 1A shows that approximately $25 \%$ of the proteins from seed extract formed a strong interaction with 

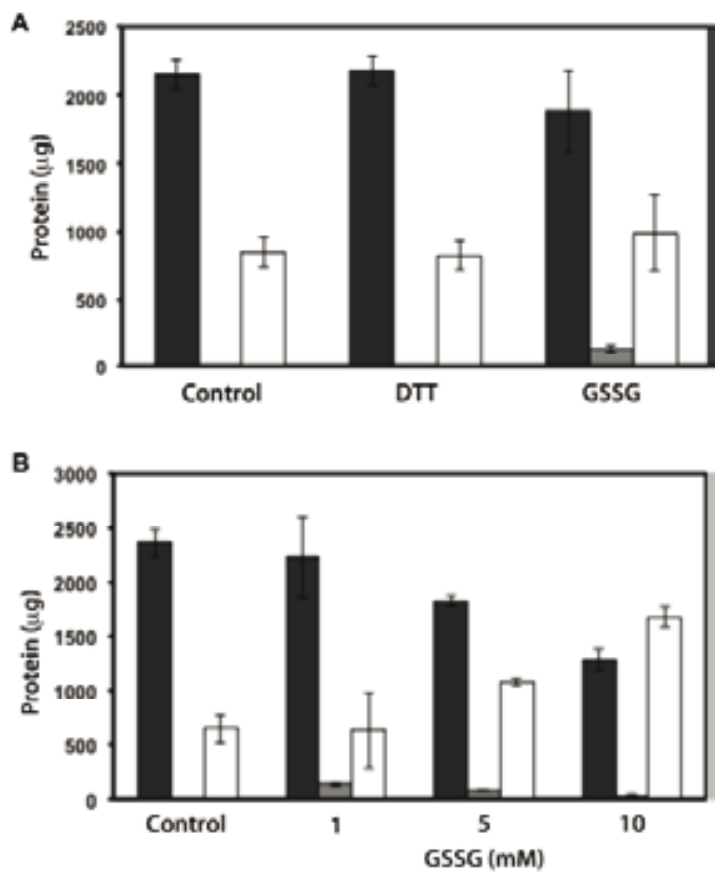

Fig. 1. GSSG promotes the interaction of proteins from bean seeds with potato starch. (A) Effect of DTT and GSSG $(1 \mathrm{mM})$ on the association of proteins from bean seeds to starch granules. (B) Effect of GSSG concentration on protein binding to the starch. The protein fraction not bound to starch (ם), recovered by washing the starch with $5 \%$ glucose ( $\square)$ and remaining associated to the granules $(\square)$ are indicated.

potato tuber starch; DTT $(1 \mathrm{mM})$ did not have any significant effect, while GSSG $(1 \mathrm{mM})$ increased the amount of protein associated to starch. On the other hand, a small fraction of the proteins bounded in the presence of GSSG was released by washing with 5\% glucose solution. By increasing GSSG up to $10 \mathrm{mM}$, the protein fraction associated to the granules reached $60 \%$. The interaction was also more stable and the amount of released proteins by washing with $5 \%$ glucose solution was reduced as GSSG concentration was increased (Figure 1B). Therefore, the effect of higher glucose concentrations on releasing proteins associated to starch in the presence of $10 \mathrm{mM}$ GSSG was then investigated. Figure 2A shows that washing with glucose up to $20 \%$ was unable to increase the amount of protein released. Neither mannose, fructose nor mannitol at $20 \%$ were effective (Figure 2B). We further investigated if the interaction promoted by the oxidative environment created by GSSG could be reverted by a reducing agent such as DTT. In order to do it, proteins were first incubated with starch in the presence of $10 \mathrm{mM} \mathrm{GSSG}$ and after removing free GSSG, starch was then washed with DTT up to $50 \mathrm{mM}$. Our results (Figure 3A) showed that this treatment did not increased the amount of liberated proteins. To investigate the nature of the interactions that GSSG promoted between starch and bean seed proteins and why DTT was unable to release starch bound proteins in the presence of GSSG, the starch was treated with 1 or $10 \mathrm{mM}$ GSSG, then washed and incubated with $50 \mathrm{mM}$ DTT. DTT was removed and the proteins were finally added. Figure
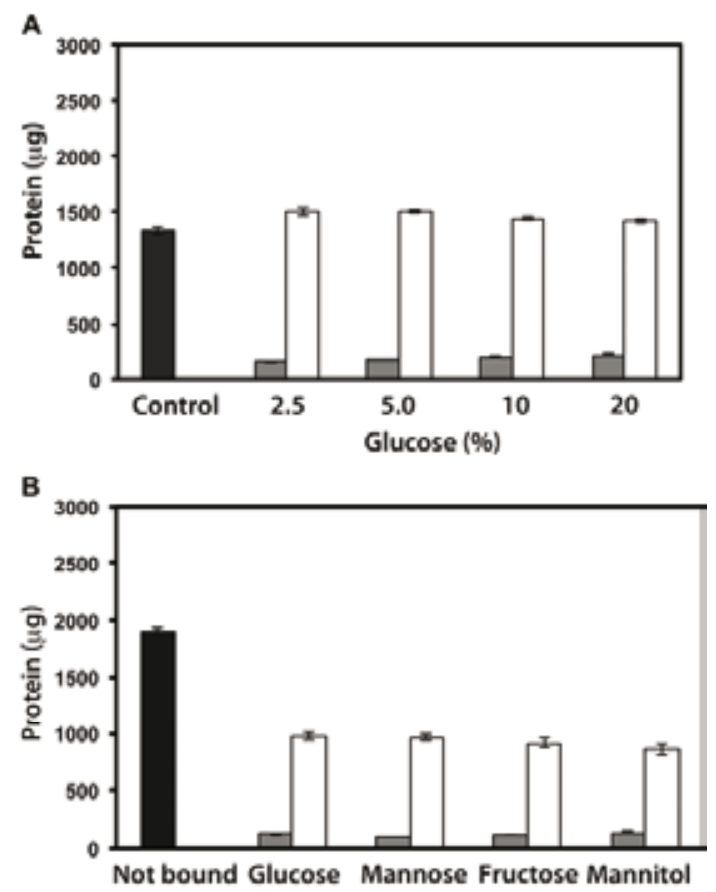

Fig. 2. Effect of sugars on the release of proteins associated to starch granules. (A) Increasing glucose concentrations were used to wash and release bound proteins to starch granules in the presence of $10 \mathrm{mM}$ GSSG. (B) Effect of washing with different sugars on the release of proteins. The protein fraction not bound to starch (ם), recovered by washing with $20 \%$ of the indicated sugar $(\square)$ and remaining associated to the starch $(\square)$ are indicated.

3B shows that under these conditions, DTT was very effective at preventing the binding of proteins to the starch. Together, these data show that GSSG favors the association of bean seed proteins with starch and increases the stability of the interaction (Figure 1B). This may be the result of the changes that this treatment induces on both the proteins and the starch granules. Protein susceptibility to oxidation by GSSG depends on the presence of reactive cysteine residues [12]. We observed that with $10 \mathrm{mM} \mathrm{GSSG}$, the bean seed proteins formed aggregates (data not shown), suggesting that some proteins with reactive residues could increase their binding capacity as a result of the changes induced by GSSG. In addition, DTT was very effective at preventing the effects of GSSG on protein binding, but only if it is added before the incubation with the protein mixture (Figure 3B); otherwise, DTT was non-effective at releasing the proteins after GSSG treatment (Figure 3A). This suggests that GSSG also modified the starch surface, but after the interaction starch:protein is formed, DTT was unable to release the proteins because it is no longer able to reach the sites affected by GSSG.

As a result of the binding of proteins from bean seeds to potato starch granules, the ability to absorb water by the granules was significantly increased (Figure 4A). This could be important for applications were starch is used to increase the viscosity of processed foods. However, the amount of water retained by gelatinized starch was not affected (Figure 4B). Proteins associated to starch can act as a barrier to the release 

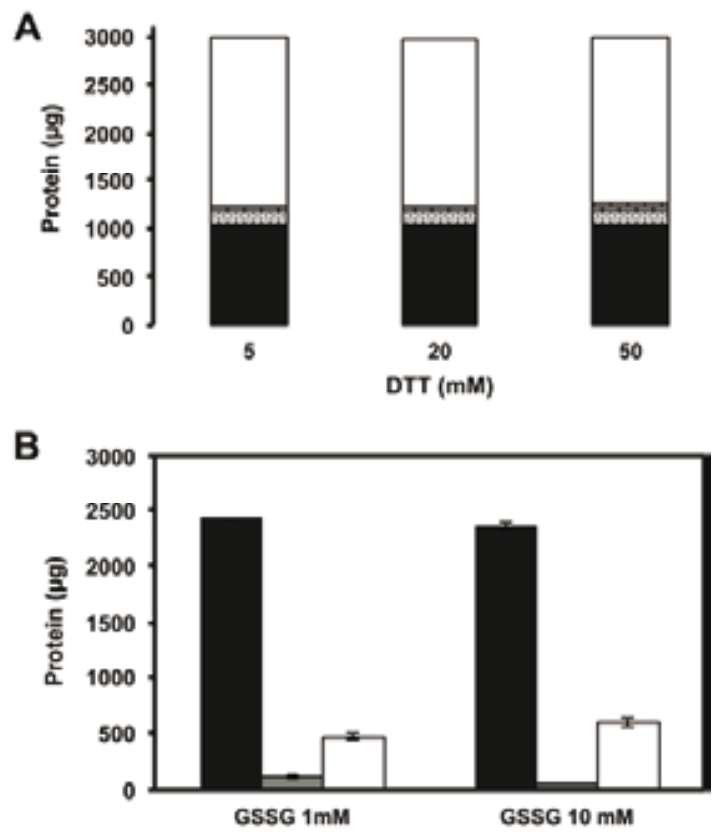

Fig. 3. Effect of DTT on the interaction of starch with proteins from bean seeds. (A) The effect of DTT on the release of proteins associated to starch in presence of $10 \mathrm{mM} \mathrm{GSSG}$. The unbound protein fractions ( $\square$ ), eluted by washing first with $20 \%$ glucose (II) and then

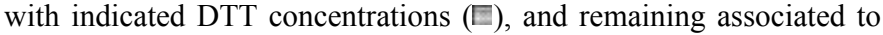
starch ( $\square$ ) are indicated. (B) Binding of proteins to starch previously treated with GSSG $(10 \mathrm{mM})$ and DTT $(50 \mathrm{mM})$. Unbound protein

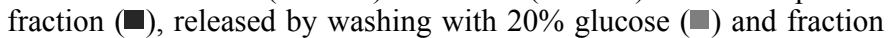
that remained associated to the starch $(\square)$.

of amylose [13]. Since the hydrophilicity of the proteins is relevant for the interaction with starch [14], it will be needed to investigate how the interactions between starch and proteins from different sources are affected by GSSG and the impact of this treatment has on starch properties.

\section{Experimental}

Starch purification from potato tubers [15]. Tubers were rinsed in water, peeled and then, cut into small cubes. Tuber cubes $(400 \mathrm{~g})$ were blended with $400 \mathrm{ml}$ water at low speed for $45 \mathrm{~s}$. The mixture was allowed to stand for $20 \mathrm{~min}$, and the liquid was decanted away from the sediment. The sediment was resuspended in water and passed through a U.S. No. 20 sieve. The retained material was washed on the sieve with water, resuspended in water, macerated for $45 \mathrm{~s}$ and finally passed through the same sieve. Starch was allowed to settle for 30-45 min, and the supernatant was decanted. The starch was resuspended in water and passed through a U.S. No. 60 sieve. The filtrate was allowed to settle, and the supernatant was discarded. The starch was dried in a convection oven at $50^{\circ} \mathrm{C}$ and then ground with a mortar and pestle to pass it through a U.S. No. 60 sieve.

Bean seed proteins. Bean seeds (cv Flor de Mayo) were ground in a mortar and passed through a U.S. No. 200 sieve. The powder ( $2 \mathrm{~g}$ ) was resuspended in $3 \mathrm{ml}$ of extraction buffer
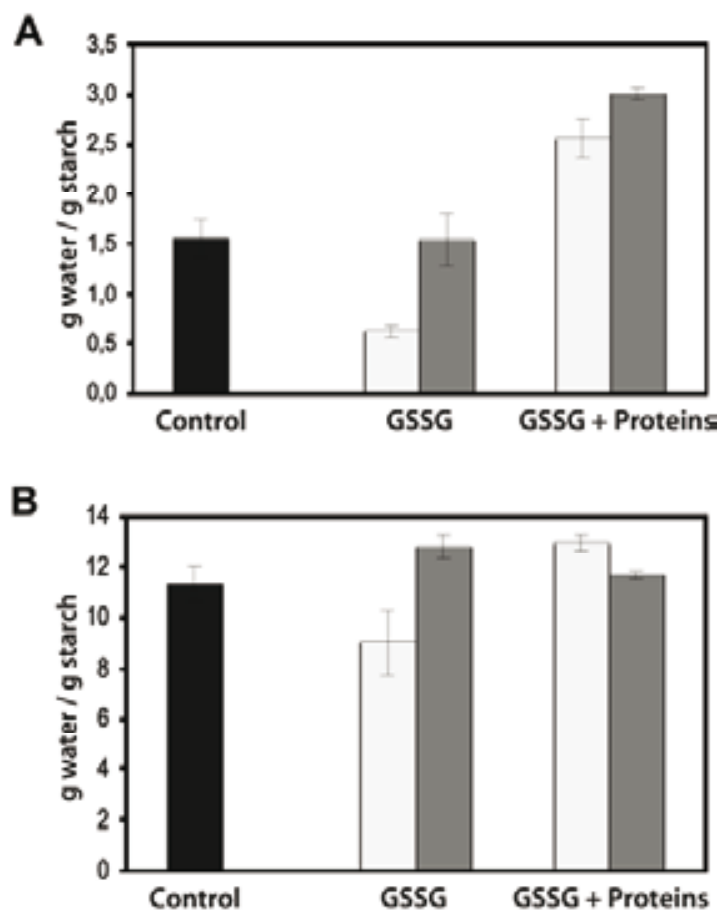

Fig. 4. Water absorption capacity and swelling power of starch treated with GSSG and proteins from bean seeds. Water absorption capacity (A) and swelling power (B) of starch control (Ш) and treated with 1 $\mathrm{mM}(\square)$ and $10 \mathrm{mM}$ GSSG ($\square)$ with or without bean seed proteins.

(10 mM Tris- $\mathrm{HCl}, \mathrm{pH} 7.4,1 \mathrm{mM} \mathrm{MgCl}_{2}, 1 \mathrm{mM} \mathrm{CaCl} 2$ ) and mixed for $1 \mathrm{~h}$ in a rotating wheel at $4{ }^{\circ} \mathrm{C}$. The material was centrifuged for $20 \mathrm{~min}$ at $10,000 \times \mathrm{g}$. Protein concentration in the supernatant was determined by the Bradford method [16].

Starch: protein interaction. Starch granules $(50 \mathrm{mg})$ were washed twice with water and three times with extraction buffer. Washed starch was suspended in extraction buffer and mixed with $3 \mathrm{mg}$ of protein from bean seeds and either DTT or GSSG at indicated concentrations in a final volume of $1 \mathrm{~mL}$ and mixed for $1 \mathrm{~h}$ in a rotating wheel at $4{ }^{\circ} \mathrm{C}$. Unbound proteins were recovered in the supernatant after centrifugation for $20 \mathrm{~min}$ at 10,000 $\times \mathrm{g}$. The pellet was resuspended in $1 \mathrm{~mL}$ extraction buffer and washed three times. Then, it was resuspended in $200 \mu \mathrm{L}$ of sugar solution (glucose, mannose, fructose or mannitol in different concentrations as indicated), thoroughly mixed with vortex for $20 \mathrm{~min}$ and centrifuged for $20 \mathrm{~min}$ at $10,000 \times \mathrm{g}$. Released proteins with sugar solutions and proteins in unbound fraction were determined by the Bradford method [16]. The amount of proteins that remained associated to the granule surface was estimated by subtracting the protein present in the bound and released fractions to the total quantity used in the assay.

Water absorption capacity and swelling power [17]. Water absorption capacity was measured in starch $(50 \mathrm{mg})$ treated with GSSG (1 and $10 \mathrm{mM})$ or in starch blended with GSSG and bean seed proteins $(3 \mathrm{mg})$. Starch was resuspended in $1 \mathrm{~mL}$ water and incubated for $1 \mathrm{~h}$ at room temperature in a rotating wheel. The suspension was centrifuged for $5 \mathrm{~min}$ at $5,000 \times \mathrm{g}$. Then, it was decanted and the granules were weighed. Water absorption capacity was calculated by comparing the final weight 
with the initial one. The swelling power of the same samples was determined by measuring the amount of water absorbed by gelatinized starch. Starch suspensions were kept in a water bath at $90{ }^{\circ} \mathrm{C}$ for $10 \mathrm{~min}$. After cooling, samples were centrifuged for $5 \mathrm{~min}$ at $5,000 \times \mathrm{g}$ and the supernatants discarded. Weight of the swollen granules was used to calculate this parameter.

\section{Acknowledgments}

We are especially grateful to Laurel Fabila and Carmen Parra for the skillful technical assistance. This work was supported by DGAPA-UNAM (IN217811) and PAIP-FQ (6290-14).

\section{References}

1. Ellis, P. R.; Cochrane, M. P.; Dale, M. F. B.; Duffus, C. M.; Lynn, A.; Morrison, I. A.; Prentice, R. D. M.; Swanston, J. S., Tiller, S. A. J. Sci. Food Agric. 1998, 77, 289-311.
2. BeMiller, J. N. Starch 1997, 4, 127-131.

3. Baldwin, P. M. Starch 2001, 53, 475-503.

4. Eliasson, E.; Tjerneld, E. Cereal Chem. 1990, 67, 366-372.

5. Chedid, L.; Kokini, J. Cereal Chem.1992, 69, 551-555.

6. Huerta-Abrego, A.; Segura-Campos, M.; Chel-Guerrero, L.; Betancourt-Azcona, D. Food Technol. Biotechnol. 2010, 48, 36-41.

7. Ryan, K. J.; Brewer, M. S. Food Chemistry. 2007, 104, 619-629.

8. Sokolov, L. N.; Dominguez-Solis, J. R.; Allary, A.-L.; Buchanan, B. B.; Lua, S. PNAS. 2006, 103, 9732-9737.

9. Meyer, A.; Hell, R. Photosynth Res. 2005, 86, 435-457.

10. Cairns, N. G.; Pasternak, M. J.; Wachter, A.; Cobbelt, C. S.; Meyer, A. J. Plant Physiol. 2006, 141, 446-455.

11. Awasuhara, M.; Kim, H.; Hayashi, H.; Chino, M.; Kim, S.-G.; Fujiwara, T. Biosci. Biotechnol. Biochem. 2002, 66, 1751-1754.

12. Dalle-Donne, I.; Rossi, R.; Colombo, G.; Giustarini, D.; Milzani, A. Trends in Biochem. Sciences 2009, 34, 85-96.

13. Bejosano, F.P.; Corke, H. Food Chemistry, 1999, 65, 493-501.

14. Yamazaki, W. T.; Donelson, J. R.; Kwolik, W. F. Carbohydrates 1977, 54, 352-360.

15. Wiesenborn, D. P.; Orr, P. H.; Casper, H. H.; Tacke, B. K. J. of Food Sci. 1994, 59, 644-648.

16. Bradford, M. M. Anal. Biochem. 1976, 72, 248-254.

17. Lii, C.-Y.; Tsai, M.-L.; Tseng, K.-H. Carbohydrates 1996, 73, 415-420. 